\title{
Nurse-led telephone referral to paediatric emergency and assessment units
}

\author{
Claus Sixtus Jensen \\ From Danish Society for Emergency Medicine: Research Symposium 2010 \\ Roskilde, Denmark. 20-21 May 2010
}

\begin{abstract}
Background
An increasing number of acute referrals have led to unsatisfactory working conditions and a degradation of the service to the families and their children attending paediatric emergency and assessment units (PEAU). The usual way of refering for the general practitioner (GP) was by telephone to the resident. This study investigated if a nurse-led telephone referral system would optimize conditions for patients and staff.
\end{abstract}

\section{Methods}

The project period was from October to December 2009. A team of five paediatric nurses were in charge of the nurse-led referral system with backup from the attending physician. Prior to the project the nurses were introduced to a flowchart on documention of the referrals and a guideline to obtain essential information about the child's condition. The guideline also included a model to ensure efficient and accurate reception and transmission of information - the ISBAR communikation model. The project was evaluated using an electronic questionnaire and focus group interviews.

\section{Aim}

* To create optimal continuity of care

* Optimise service to GPs and other collaborators

* Improve quality of care to the families

* To improve working conditions in the PEAU

\section{Results}

Nurse-led telephone referral ensured:

* Optimal continuity of care as the nurses in charge of referral had a better overview

Correspondence: claus.sixtus@skejby.rm.dk

Department of Paediatrics, Aarhus University Hospital, Skejby, Denmark
* Improved working procedures as information about the children were already documented prior to arrival to the PEAU

* Better working environment as staff was able to examine the children and talk to the families without interruptions

* An improved quality of the referral system according to the GPs

\section{Conclusion}

A nurse-led referral system to a PEAU has proven succesfull and staff reported improved working conditions. Furthermore did the project shed a light on the imortance of a valideted triage tool to prioritize acutely admitted children. As a result of this has the PEAU commenced a project in order to develop a paediatric triage tool.

Published: 17 September 2010

doi:10.1186/1757-7241-18-S1-P23

Cite this article as: Jensen: Nurse-led telephone referral to paediatric emergency and assessment units. Scandinavian Journal of Trauma, Resuscitation and Emergency Medicine 2010 18(Suppl 1):P23.

Submit your next manuscript to BioMed Central and take full advantage of:

- Convenient online submission

- Thorough peer review

- No space constraints or color figure charges

- Immediate publication on acceptance

- Inclusion in PubMed, CAS, Scopus and Google Scholar

- Research which is freely available for redistribution

Submit your manuscript at www.biomedcentral.com/submit 